\title{
ORCIDアウトリーチ·ミーティング in シカゴ
}

\author{
日程 2014 年5月21日(水), 22日(木) \\ 場 所 米国シカゴ(Chicago, USA), イリノイ大学(University of Illinois) \\ 主 催 ORCID, Inc
}

情報管理５7(6)，423-428, doi: 10.1241/johokanri.57.423 (http://dx.doi.org/10.1241/johokanri.57.423)

\section{1.はじめに}

2014年5月21，22日，イリノイ大学（米シカゴ）に てORCIDアウトリーチ・ミーティング (以下， ORCID シ力ゴ会議) 注1) が開催された（図1，図2）。

ORCID（オーキッド）(http://orcid.org/) とは， Open Researcher \& Contributor IDの略称で，世界

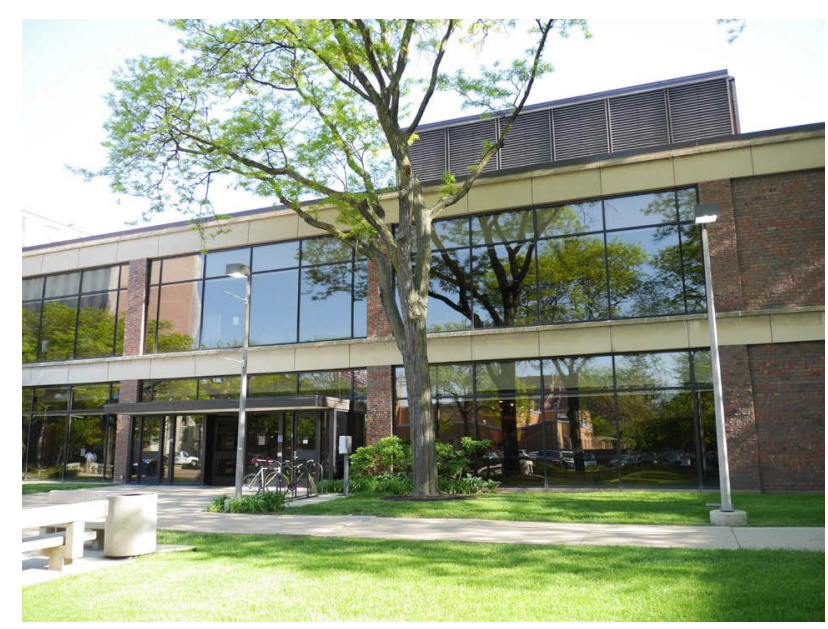

図1 ORCIDシカゴ会議の会場となったイリノイ大学

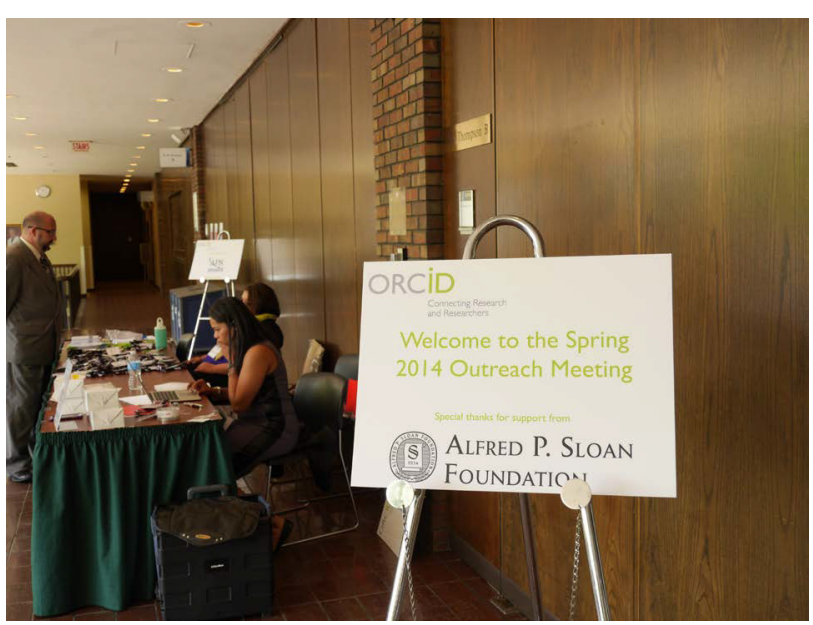

図2 ORCIDシカゴ会議の受付
中の研究者に一意の識別子を与えることを目指す国 際的な非営利組織である1)。そのORCIDが主催する ORCIDアウトリーチ・ミーティングは，研究機関や 学術系出版社・研究助成機関・研究者などが，導入 事例報告等を情報共有することを目的に年に2度，欧 米で交互に開催されている。今回7回目（表1）となっ たORCIDシカゴ会議には，大学図書館員を中心に約 160名の参加があった。

著者は2013年8月に国内初となるORCIDアンバサ ダー注2) (ORCID普及を促すボランティア)に認定され， 同年秋に開催された図書館総合展でポスター発表注3) するなどORCID普及を後押ししてきた。今回，ORCID シカゴ会議開催を記念して開発した，文献管理サー ビスMendeleyとORCIDの統合ツール「Mendeley to ORCID」のポスター発表を目的にORCIDシカゴ会議 に参加した。ORCIDシカゴ会議には著者を含め11名 のORCIDアンバサダーの参加があり，彼ら/彼女ら との交流をはかるのも目的のひとつであった。なお， 本稿執筆時点で27か国に83名のORCIDアンバサダー がいる(アジア環太平洋地域16名，ヨーロッパ・中 東およびアフリカ27名，南北アメリカ40名［2014年 7月現在])。

本稿では「ORCIDとは何か」を改めて確認した後 に，発表されたORCID導入事例を一部紹介する。また， 同時に開催されたコードフェスト（ハッカソン）の 様子や，著者自身によるポスター発表についても報 告する。 
表1 これまでのORCIDアウトリーチ・ミーティング

\begin{tabular}{|c|c|c|c|}
\hline 開催数 & 開催時期 & 開催場所 & 備考 \\
\hline 第 1 回 & 2011 年 5 月 18 日 & $\begin{array}{l}\text { 米国ボストン } \\
\text { (Boston, USA) }\end{array}$ & \\
\hline 第 2 回 & 2011 年 9 月 16 日 & $\begin{array}{l}\text { スイス欧州原子核研究機構 } \\
\text { (CERN, Switzerland) }\end{array}$ & \\
\hline 第 3 回 & 2012 年 5 月 17 日 & $\begin{array}{l}\text { 米国ボストン } \\
\text { (Boston, USA) }\end{array}$ & \\
\hline 第 4 回 & 2012 年 10 月 17 日 & $\begin{array}{l}\text { ドイツ ベルリン } \\
\text { (Berlin, Germany) }\end{array}$ & \\
\hline 第 5 回 & 2013 年 5 月 $23 ， 24$ 日 & $\begin{array}{l}\text { 英国オックスフォード } \\
\text { (Oxford, UK) }\end{array}$ & コードフェスト開催 \\
\hline 第 6 回 & 2013 年 10 月 30 日 & $\begin{array}{l}\text { 米国ワシントン D.C. } \\
\text { (Washington D.C., USA) }\end{array}$ & \\
\hline 第 7 回 & 2014 年 5 月 $21 ， 22$ 日 & $\begin{array}{l}\text { 米国シカゴ } \\
\text { (Chicago, USA) }\end{array}$ & コードフェスト開催 \\
\hline
\end{tabular}

出典 : http://orcid.org/about/events

\section{ORCIDシカゴ会議}

初日は，アルフレッド・P・スローン財団（以下， スローン財団）およびイリノイ大学の開会挨拶で幕 を開け，主催のORCIDよりローレル・ハーク氏（エグ ゼクティブ・ディレクター)，レベッカ・ブライアン ト氏（コミュニティー・ディレクター)，ローラ・パ リオーネ氏（テクニカル・ディレクター）の3名から ORCIDの現状や今後のプラン，コミュニティー活動や 開発体制などについての報告があった（図3，図4)。

それらの発表から，あらためてORCIDとは何かを まとめる。

\subsection{ORCIDとは}

ORCIDは，研究者の名寄せ問題を解決しようと立 ち上がったプロジェクトである。同姓同名や婚姻に

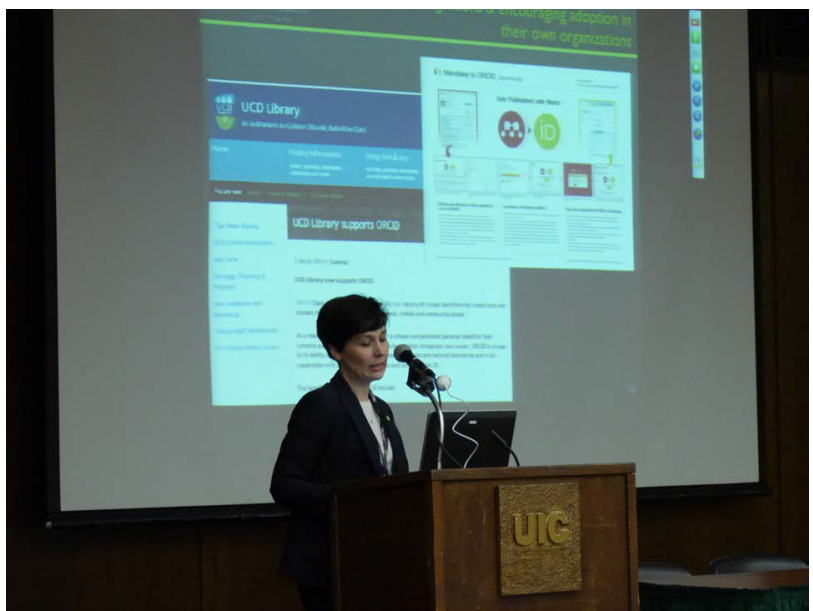

図3 ORCIDのコミュニティー活動を紹介する レベッカ・ブライアント氏

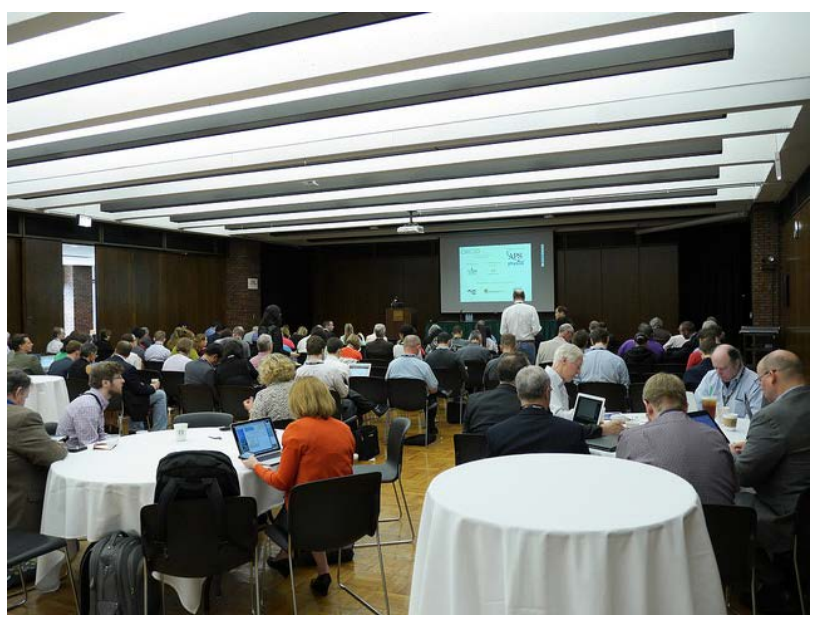

図4 ORCIDシカゴ会議の風景

よる姓の変更により同一人物を特定できないことな どが問題意識としてあった。ORCIDの類似サービス としてResearcherlD（トムソン・ロイター） (http:// www.researcherid.com/)，国内であればresearchmap (科学技術振興機構・国立情報学研究所) (http:// researchmap.jp/) などが挙げられる。ORCIDは国際 標準としてこうした既存のIDサービスを連携・統合 し，ユニバーサルな研究者IDとして機能することを目 指しており，出版社・研究機関を中心にそれを実現 可能にするAPI公開・導入事例が広がりをみせている。

ORCIDは2012年10月からID（以下，ORCID iD）取 得受け付けをWebサイトで開始しており，誰でも無 料で簡単に取得できる（公式サイトには，「30秒で取 得できる」と記載されている)。ORCID iDは16桁の数 
字で構成されており，たとえば著者のORCID iDは次 のとおり (下線部分の16桁) である。

http://orcid.org/0000-0003-0485-8891

ORCID iD取得後は自身のプロフィールや業績デー タを登録することができる。公開・非公開の情報設 定がきめ細かくでき，どのような助成を受けたのかと いったファンディング情報も入力可能である。ORCID $i D$ 取得受け付け開始から約1年半たった2014年7月， 80 万人を超える研究者がORCID iDを取得している。

国別の利用状況の割合は圧倒的に米国が高く（全 体の16\%)，次が中国である $(10 \%)$ 。中国では漢字 表記からアルファベット表記にした際に同姓同名と なるケースが非常に多い。ORCIDが研究者とその関 係者の問題を解決してくれるものとして受け入れら れたと想像する (後述)。

ORCID公式サイトのローカライズも進んでいる。 スペイン語・フランス語・中国語・韓国語のほか, ポルトガル語・ロシア語・日本語が順次公開の予定で， 文字どおり世界中に広まってきている。

エルゼビアやネイチャー・パブリッシング・グルー プといった大手学術系出版社が論文投稿の際に，あ るいは研究助成機関大手のウェルカム・トラストが 助成申請の際にORCID iDの入力を求めるなどORCID 対応が進む一方，大学における導入事例も相次いで いる。今回のORCIDシカゴ会議でも事例発表の目玉 となったORCID登録採用・実装支援プログラムや， 英国情報システム合同委員会（The Joint Information Systems Committee: JISC）が支援するORCID試行プ ロジェクト注4) がそれである。

\section{2 事例報告：ORCID登録採用・実装支援プログラム}

2日間のORCIDシカゴ会議における話題の中心は， 2013年10月に発表されたORCID採用・実装支援プロ グラム (ORCID Adoption and Integration Program) 参加の9機関による導入事例報告であった（表2）。

ORCID採用・実装支援プログラムは，スローン財 団から得た助成金を，公募により募集・審査のうえ 採用決定した大学・研究団体等に対し（北米のみ対
表2 ORCID採用・実装支援プログラム参加9機関の導入事例

\begin{tabular}{|c|c|}
\hline 機関名 & 導入事例 \\
\hline $\begin{array}{l}\text { ボストン大学 } \\
\text { (Boston University) }\end{array}$ & $\begin{array}{l}\text { 研 究 者プロフィールプラットフォーム } \\
\text { Profiles との統合 }\end{array}$ \\
\hline $\begin{array}{l}\text { コーネル大学 } \\
\text { (Cornell University) }\end{array}$ & 学際的研究ネットワーク VIVO との統合 \\
\hline $\begin{array}{l}\text { ノートルダム大学 } \\
\text { (University of Notre Dame) }\end{array}$ & $\begin{array}{l}\text { 機 関リポジトリ（Hydra stack/Fedora } \\
\text { Commons）との統合 }\end{array}$ \\
\hline \begin{tabular}{|l} 
パデュー大学 \\
(Purdue University)
\end{tabular} & $\begin{array}{l}\text { 共同研究支援システム HUBzero との } \\
\text { 統合 }\end{array}$ \\
\hline Reactome & $\begin{array}{l}\text { 生物学的プロセスやパスウェイに関す } \\
\text { る情報を含むデータベースとの統合 }\end{array}$ \\
\hline $\begin{array}{l}\text { 北米神経科学学会 } \\
\text { (Society for Neuroscience) }\end{array}$ & $\begin{array}{l}\text { 学会 管 理 システム (Association } \\
\text { Management System: AMS) Personify } \\
\text { との統合 }\end{array}$ \\
\hline $\begin{array}{l}\text { テキサス A \& M 大学 } \\
\text { (Texas A\&M University) }\end{array}$ & $\begin{array}{l}\text { 電子学位論文 (Electronic Theses and } \\
\text { Dissertations: ETD) システム Vireo と } \\
\text { の統合 }\end{array}$ \\
\hline $\begin{array}{l}\text { コロラド大学 } \\
\text { (University of Colorado) }\end{array}$ & $\begin{array}{l}\text { 学部情報システム（Faculty Information } \\
\text { System: FIS）との統合 }\end{array}$ \\
\hline \begin{tabular}{|l} 
ミズーリ大学 \\
(University of Missouri)
\end{tabular} & $\begin{array}{l}\text { 機関リポジトリ（DSpace ベース）との } \\
\text { 統合 }\end{array}$ \\
\hline
\end{tabular}

出典 : http://orcid.org/blog/2013/09/27/announcing-orcid-adoptionintegration-program-awardees

象)，ORCID採用・実装を資金面でサポートするもの である。本プログラムの実行により導入事例報告や 開発コードのオープンソース化を推進し，その他の 機関におけるORCIDの潜在二ーズを高めることを目 的としている。

著者が特に注目したのは，機関リポジトリ（ノー トルダム大学・ミズーリ大学）との連携である。現 在，世界中に2,600以上存在する機関リポジトリのう ち、約42\%がDSpaceをべースに構築されている注5)。 ミズーリ大学が取り組んでいるのは，このDSpaceに よって構築された機関リポジトリとORCIDの連携で， 実現された機能が2014年秋以降，他のDSpace利用機 関にも開放される予定である。機関リポジトリで圧 倒的なシェアを誇るDSpace利用機関へのORCID普及 が期待できる。

国内に目を向けると，日本には約350の機関リポジ トリが存在する注6)。OpenDOAR上では，日本の機関 リポジトリ登録数は145で，その約68\%がDSpaceを 利用している。一方で，国立情報学研究所の共用リ ポジトリサービス「JAIRO Cloud」注7)への参加申請 機関が200以上と半数を超えている。

2014年5月21日，まだJAIRO Cloudが存在しなかっ 
た2007年にDSpaceで機関リポジトリ「つくばリポ ジトリ」(Tulips-R) を構築した筑波大学が，JAIRO Cloudに移行した。運用・資金面からも今後多くの機 関が筑波大学と同様の動きをみせる可能性がある。 したがって，JAIRO CloudのORCID対応が進めば，日 本はORCID対応先進国としての期待が高まる。

これに加えてresearchmapとの連携や，KAKEN（科 学研究費助成事業データベース)・CiNii（NII学術ナ ビゲータ［サイニイ）におけるORCID対応にも期待 したい。著者は特に，約 23 万人以上の研究者登録が あるresearchmapのORCID対応を待ち望んでいる。 現在はORCIDからの情報取り込み機能しかないが， researchmapからORCIDへの情報移行・同期機能など が実現されれば，日本人研究者にとっても情報を何度 も登録する手間が省けるなど，利用を後押しするので はないかと考える。researchmapを運用面・開発面か ら支える科学技術振興機構と国立情報学研究所はと もにORCIDのメンバ一機関であり，大いに期待したい。

\section{3 アジアで存在感を示す中国：清華大学の報告}

アジア勢においてもっともORCID対応に意欲的だ と感じたのは，9名もの参加があった中国の清華大学 である（図5）。名寄せ問題を痛烈に感じている中国 ならではの事情があるからであろう。発表された清 華大学のイェン・シュワイ教授によると，たとえば 図書館情報学における59名の有名な研究者について 調べたところ，11名もが「王芳」(Wang Fang）とい う名前だったという。同じ分野で11名も同姓同名と なると，どの王芳 (Wang Fang) 先生が自分の知り

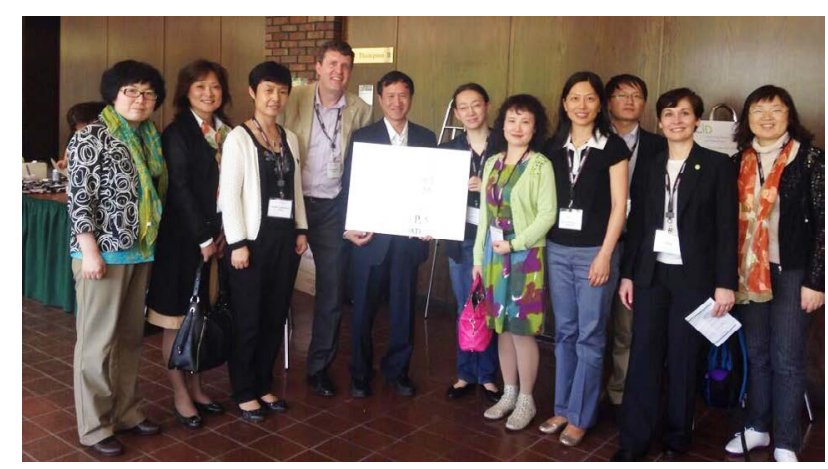

図5 清華大学（中国）の参加者たち
たい先生なのか混乱してしまうことが容易に想像で きる。

一方，中国の論文数が世界2位，中国の研究者数 倍増といった話題がある。世界全体の論文数に占 める各国の論文数・割合（論文数シェア）でみる と，1990年代後半からは中国における論文数が飛躍 的に増加し，中国の論文数シェアは2008年において $10.5 \%$ と世界第2位（日本の同年における論文数シェ アは7.0\%で5位）である。その背景にある2001年と 2008年の研究者数を比較すると，日本は，研究者数 に変化はほとんどなくほぼ横ばいで約65万人である のに対し，中国の研究者数は，2001年から年々増加 傾向にあり，2008年には約2.1倍となっている。論文 数も研究者数も，数が増えれば増えるだけ研究者の 同姓同名問題が頭痛の種になるわけである。

そこでORCIDに問題の糸口を見いだし，その結果， 現実にORCID iDの発行数でいえば中国が世界第2位と なることも納得のいく話である。

清華大学ではまだ特にORCID実装をしたわけでは ないが，イェン教授が発表されたサーベイから，中 国におけるORCID普及の可能性は日本より高いこと が理解できる。

\section{4 コードフェスト}

コードフェスト (CodeFest) とは, 普段はインター ネット上でのやり取りのみで，直接話し合う機会が あまりないハッカーたちが1か所に集い，自由にソー スコードを持ち寄って顔を合わせて議論しながら開 発を進めるイベントである。昨年（2013年5月／英国 オックスフォード）に引き続き2回目の開催となり， こちらは静かに，しかし熱く開発が進められた(図6)。

昨年は11のプロジェクトから「OrcidLIVE!」という ORCIDとGoogleマップをマッシュアップしたサービ スが優勝した。今回もどんなコードが披露されるの か楽しみにしていたイベントの1つである。今回は6 つのプロジェクトがエントリーされ，ORCIDの更新 情報をツイートする「Orcid Social」やブログサービ スWordpressのプラグインなど，身近で旬なコードが 


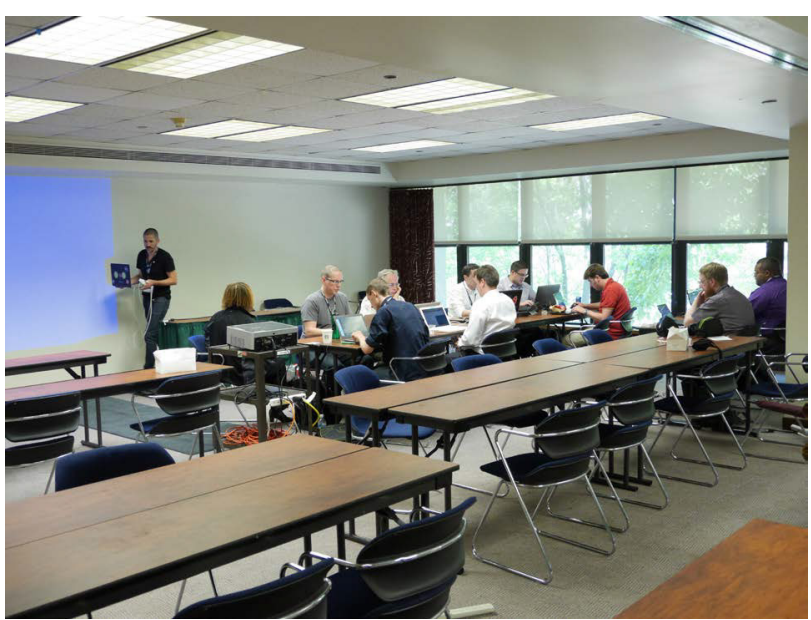

図6コードフェスト開催中の風景

開発された（図7）。

$2.5\lceil$ Mendeley to ORCID」ポスター発表：ORCIDアン

バサダーたちとの交流

ORCIDシカゴ会議ではイベント・プログラムのほか

に，会場内外でポスター発表や企業ブース展示があっ た。ポスターは10の発表があったが，そのうちの1つ が著者のものであり，MendeleyとORCID双方のAPI を利用して開発したサービス「Mendeley to ORCID」 (http://m2id.org/) を発表した。これほど短期間で多 くのORCID iDの発行があった背景には，ORCIDが早 期にAPIを公開したことと，Scopusやfigshareなどの サービスによるORCID統合ツールが普及してID取得 を後押したことがあると著者は考えている2)。

そこでORCIDアンバサダーとして，さらなるORCID

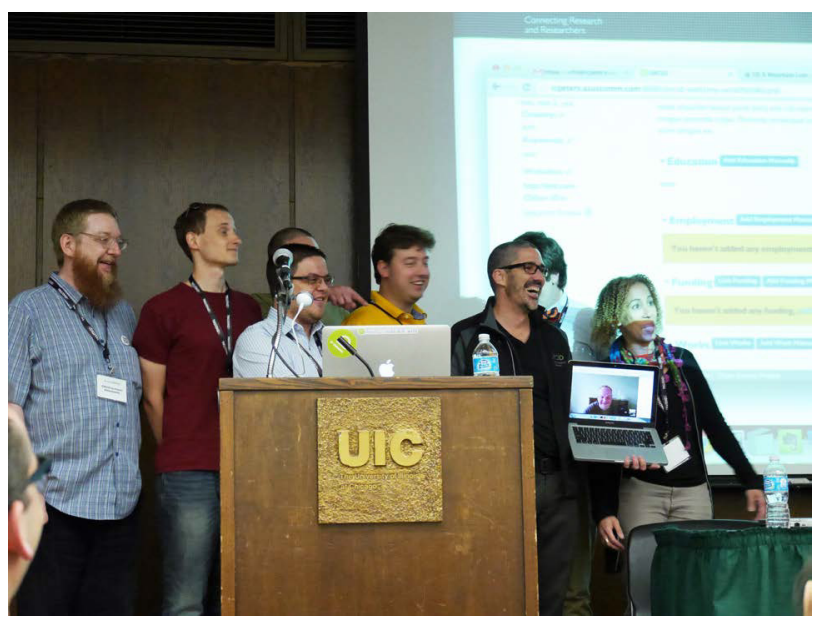

図7 コードフェスト表彰の様子
iD取得を促すことを目的に，300万人を超える世界 中の研究者が利用するMendeleyに着目してORCID 統合ツールを発案した。Mendeleyユーザーの多く が自身の出版物情報を含むプロフィールを管理して いると想定し，ORCIDシカゴ会議直前に，Mendeley のPublicationsをORCIDのWorksへ簡易に連携させる ツールのサービスを提供するに至った3)。

ポスターの前で事前に用意したペンを参加者に渡 し，ポスターに直接コメントや名前のサインをお願 いしてコミュニケーションをはかった。ORCIDアン バサダーや会議参加者たちと大変有意義な時間を過 ごすことができた（図8，図9）。

会議当日の資料は映像とともにすべて公開されて

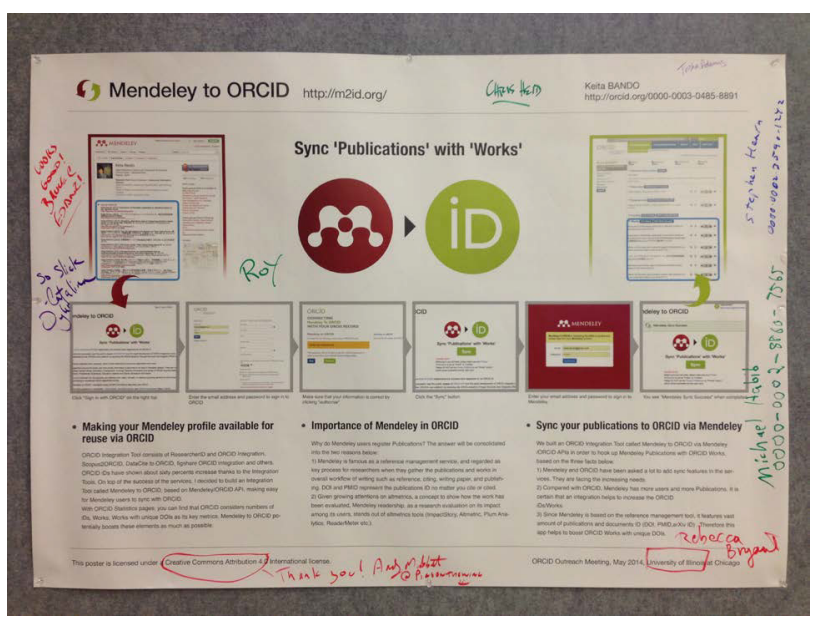

図8 著者が発表したポスターには参加者からメッセージが書き 込まれた

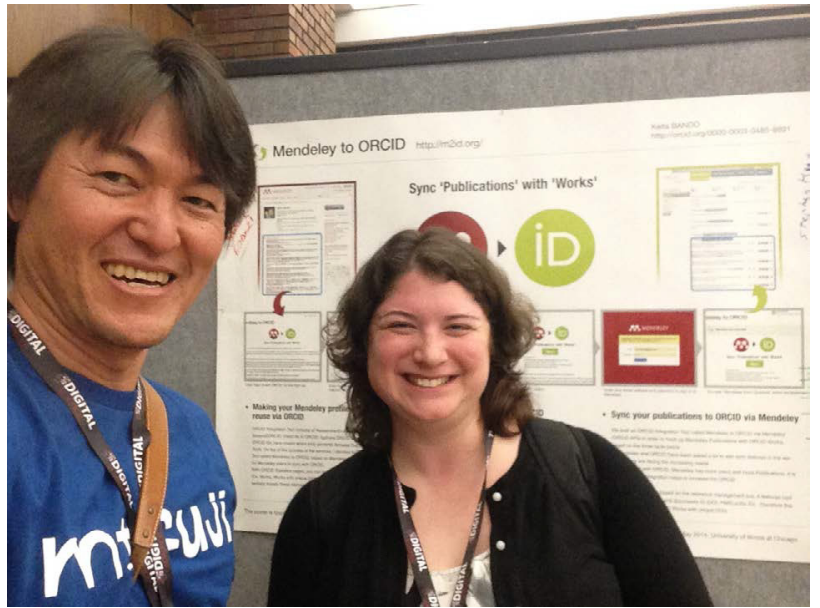

図9 他国のORCIDアンバサダーと，ポスターの前で記念撮影す る著者 (左) 
いるほか，ORCID理事のお一人であり国立情報学研 究所の武田英明教授によるTwitterのまとめ注8）も公 開されているので参考にされたい。

\section{3.おわりに：ORCIDアウトリーチ・ミーティング} in 東京, 11月開催

次回のORCIDアウトリーチ・ミーティングが，国 立情報学研究所の協力のもと，2014年11月4日に東
京で開催される注9)。これまで欧米でしか開催されな かった本ミーティングが初めてアジアで開催される とあって，アジア太平洋地域の国々におけるインテ グレーター・研究機関・国の機関や研究者から注目 されている。導入事例を学び，関係者との交流を深 めるよい機会になることを，現地プログラム委員の1 人として強く願っている。

（ORCIDアンバサダー 坂東慶太）

\section{本文の注}

注1) ORCIDアウトリーチ・ミーティング. https://orcid.org/content/orcid-outreach-meeting-and-codefestmay-2014

注2） ORCIDアンバサダー. https://orcid.org/content/orcid-ambassadors-1

注3）第15回図書館総合展でのポスター発表. http://keitabando.org/2013/11/04/orcidposter/

注4) ORCID試行プロジェクト.http://www.jisc.ac.uk/fundingopportunities/funding_calls/2014/03/orcid. aspx

注5) OpenDOARのWebサイトで検索するとデータが見られる（数字は2014年7月現在）。http://www. opendoar.org/find.php

注6）国立情報学研究所. 機関リポジトリ一覧. http://www.nii.ac.jp/irp/list/

注7）国立情報学研究所. JAIRO Cloudとは. 学術機関リポジトリ構築連携支援事業. http://www.nii.ac.jp/irp/ repo/\#1

注8) TAKEDA, Hideaki編. ORCID Outreach Meeting Chicago May 21-22, 2014. togetter. http://togetter.com/ li/670754

注9） ORCIDアウトリーチ・ミーティング in Tokyo. http://orcid.org/blog/2014/06/11/save-date-autumnorcid-outreach-meeting-tokyo

\section{参考文献}

1）蔵川圭, 武田英明. 研究者識別子ORCIDの取り組み. 情報管理. 2012, vol. 54, no. 10, p. 622-631.

2) 高橋昭治, 恒吉有紀. Scopusの著者識別機能とORCIDとの連携: 特集 研究者識別子ORCID. 薬学図書館. 2014, vol. 59, no. 2, p. 126-129.

3) Bando, Keita. Mendeley to ORCID; Poster for ORCID Outreach Meeting, 2014-05. figshare. 2014-05. http:// dx.doi.org/10.6084/m9.figshare.1032742, (accessed 2014-07-10). 